\title{
Language Performativity and Horror Fiction: A Cognitive Stylistic Approach
}

\author{
Wesam Ali El-Sayed \\ Department of English, Faculty of Al-Alsun, Minia University, Egypt \\ wesam.elsayed@mu.edu.eg
}

DOI: http://doi.org/ 10.36892/ijlls.v3i3.647

$\begin{array}{ll}\begin{array}{l}\text { Received: } \\ \text { 13/06/2021 }\end{array} & \text { Abstract } \\ \text { Accepted: } & \text { exploiting the workings of language in the minds of readers. As a genre } \\ 25 / 08 / 2021 & \text { that crosses many art forms, it might be tempting to analyze the } \\ & \text { multimodal vehicles of horror; the visual effects, the jump scares and } \\ \text { Keywords: } & \text { the ominous music. However, studying the ability of language, on its } \\ \text { Cognitive Stylistics, } & \text { own and without any audio-visual effects, to instill horror in its readers } \\ \text { Horror Fiction, } & \text { becomes even more enticing. The idea that words have the power to } \\ \text { Blending Theory, } & \text { disrupt the reality of its readers is deeply rooted in the view of language } \\ \text { Schema Theory, } & \text { as performative. The paper further argues that horror writers have } \\ \text { Conceptual } & \text { manipulate linguistic structures in a peculiar way to serve the purpose } \\ \text { Metaphor, } & \text { offrightening their readers. To this end, an eclectic text-based cognitive } \\ \text { Functional } & \text { stylistic approach is employed to analyze an excerpt from William Peter } \\ \text { Linguistics } & \text { Blatty's The Exorcist (1971), demonstrating how the process of horror } \\ \text { creation is both a textual and a cognitive one, whereby the mental } & \text { image of reality in the minds of readers is manipulated and distorted by } \\ & \text { means of linguistic structures, hence horrifying them. Results reveal } \\ & \text { that for horror to be achieved, layers of blending take place in readers } \\ \text { minds in order to arrive to horrific meanings textually described. } & \text { Additionally, manipulation of syntactic complexity and the morphology } \\ \text { of verbs intensifies the horrific effect. }\end{array}$

\section{INTRODUCTION}

Since horror fiction is "conceived to be a genre that crosses numerous artforms and media" (Carroll, 1990, p. 12), its peculiar features "are chiefly determined by the medium through which it is experienced" (Reyes, 2016, p. 9). Horror can be found in written fiction, movies, TV series, radio shows and even operas (Carroll, 1990). Unlike cinema, "which cannot help but show us images, fiction forces us to process information" (Reyes, 2016, p. 910). When it comes to horror fiction, horror writers have to put some effort into arranging linguistic structures in a peculiar way to serve their purposes of frightening their readers. As Reyes (2016) points out, "[h]orror has to work harder to create a sense of atmosphere, as it uses words...but it can also, equally, get by on very little - just what may be needed in order to disconcert or disturb" (p. 10).

This "sense of atmosphere" created by words (or lack thereof) necessitates an approach to linguistic analysis that investigates the language of literature, i.e. stylistics. Literary works have earned a place among the interests of linguists because their peculiar nature represents "attractive data" that deserve exploration (Widdowson, 1972, p. 296). 
Simpson (2004) presents a guide to the practice of stylistics as well as tackling the latest developments in the discipline, in which he introduces the cognitive addition to stylistic analysis and provides some important concepts in this new approach as well as an application of these concepts in the analysis of texts. The beginnings of integrating methods from cognitive science happened when there was an "epistemic marriage" between cognitive sciences and literary studies, which was initiated by "Lakoff and Johnson's Metaphors We Live By (1980) as the seminal work that led to a more co-ordinated interdisciplinary collaboration" (Vandele \& Brône, 2009, p.1). The resultant discipline is often termed Cognitive Stylistics and is viewed as a recent turn in the discipline (Simpson, 2004; Leech \& Short, 2007; Jeffries \& McIntyre, 2010; Stockwell, 2007); a turn which was bound to happen owing to some principles that have defined the discipline of doing Stylistics.

Stylistics, as Jeffries \& McIntyre (2010) put it, is "eclectic and open" (p. 24) and has grown into "a contextualising discipline" (p. 26), which means that it does not restrict itself to one theory or method of analysis. It is actually considered an advantage of stylistics "to remain open to new theories of language and literature, and to evolve by incorporating these new insights into its practice" (p. 24). Another defining principle of or "foundational fact" about stylistic analysis is that "meanings readers derive from a text are not sourced in the text alone, the text is not an icon or island, despite its linguistic boundedness" (Toolan, 2014, p. 17). Hence, texts cannot be studied in isolation of all the extra-linguistic factors that help bring them into existence. Therefore, to do stylistics is to acknowledge "that utterances (literary or otherwise) are produced in a time, a place, and in a cultural and cognitive context" (Simpson 2000: 3, as cited in Toolan, 2014, p. 17). Hence, this cognitive approach to stylistic analysis is a natural, inevitable step in the path that Stylistics has undertaken, or as Stockwell (2005) puts it,

The cognitive turn in stylistics is simply the latest phase in its natural development, from early formalism through pragmatics, then encompassing social, historical, cultural and now cognitive contexts. Cognitive poetics is merely the latest move in the development of stylistics. (p. 272)

Accordingly, the present paper seeks to use a cognitive stylistic approach to investigate how precisely do authors use language in order to disturb their readers. The idea that words have the power to disrupt the reality of its readers is deeply rooted in the view of language as performative, introduced in the next section.

\section{LANGUAGE PERFORMATIVITY}

The notion of language performativity began with Austin \& Searle's speech act theory. A performative view of language means that language has a tangible effect in the real world. An utterance "does not describe the world, but acts upon it - a way of "doing things with words"' (Hall, 2000, p. 184). Hence, in literature, language gains the power of creating new, even imaginary, realities in the minds of readers and forces them to share its universe of discourse. Hence, language has the power to "do more than simply describe what already exists; it can be used to create what exists only in the imagination" (Anderson, 2017, p. 6).

In the same vein, it is also important to view literature as discourse, which further asserts the "interactional dimension" of literary texts (Fowler, 1997, p. 77). From a critical discourse analytic point of view, discourse exists in an interactional relationship with society, where "language simultaneously reflects reality ("the way things are") and constructs (construes) it to be a certain way" (Gee, 1999, p. 82; emphasis in original). Hence, as put forward by Fowler (1997), to view literature as discourse "is to see the text as mediating relationships between language-users... The text ceases to be an object and becomes an action or process" (p. 77). Therefore, horror fiction, Anderson (2017) argues 
can be seen as a metalinguistic "performative" in that it brings an impossible state of affairs into being by its "utterance" ... Without saying so directly, the writer of horror fiction is, in fact, "doing something with words" by creating a world that does not exist and cannot exist under natural laws as we know them. The genre itself, then, serves as a "performative" in that the writer promises a reader that he will enter a new, imaginative world. (p. 6)

In perceiving horror fiction as discourse lies the necessity of viewing it through the lens of genre theory. Generally speaking, the term genre "is widely used in rhetoric, literary theory, media theory, and more recently linguistics, to refer to a distinctive type of 'text"' (Chandler, 1997, p. 1). Among the many approaches to genre, the structuralist approach, favored by Todorov (1975), is the most relevant one to the study of literature. Hence, to narrow the scope of definition, in literature, a structuralist approach to genre defines it as "organizing and, to some extent, shaping literary texts and activities within a literary reality" (Bawarshi \& Reiff, 2010, p. 17). In order to acquire the status of genre, any type of literary work must have the properties that allow it to enter the universe of literature as a whole and then to one of its "sub-groups," i.e. genres (Todorov, 1975). While viewing literary works as genres provides writers with a general framework within which they can express themselves, genres "structure [readers'] perceptions of literary actions, representations, and identifications" (Bawarshi \& Reiff, 2010, p. 19). Proceeding from this, it is important to give a brief history of horror in the literary tradition and how it came into being as a separate genre with linguistic peculiarities of its own.

\section{THE RISE OF HORROR AS A LITERARY GENRE}

In linguistics, the idea of genre corresponds to the notion that language is a system of choices (Halliday's Systemic Functional Linguistics) from which writers opt to use certain linguistic structures to suit their purposes. Stemming from this, as well as Halliday (1978)'s idea of register, the assumption is that when certain situation types reoccur, a linguistic tradition is developed as a result of this reoccurrence, and as Bawarshi \& Reiff (2010) note, "those who participate in these situation types develop typified ways of linguistically interacting with them" (p. 30). Accordingly, an understanding of how horror fiction, as a "situation type," gained its place and thematic peculiarities among the genres of literature is a must.

The origins of horror in literature has its roots in the "the poetry of Dante Alighieri and John Milton...[which] can also be seen as proto-horrific in places, and the Bible's 'Book of Revelation' has been the inspiration for a number of hellish horrors in Western literature" (Reyes, 2016, p. 14). However, the genesis of the present-day horror as an established genre dates back to the English gothic novel of the eighteenth century and the German Schauerromane (shudder novels) (Carroll, 1990; Reyes, 2016; Townshend, 2016). The gothic novel started in the $18^{\text {th }}$ century as a spin-off of Romantic Literature and a direct opposition to the Enlightenment and its preoccupation with scientific reason (Reyes, 2016). As Carroll (1990) puts it, the horror novel can be viewed as "the underside of the Enlightenment. Where the Enlightenment valorizes reason, the horror novel explores emotions, indeed particularly violent ones from the point of view of fictional characters" ( $p$. $56)$.

There is a consensus that the first established gothic novel is Horace Walpole's The Castle of Otranto (1764) (Carroll, 1990; Dixon, 2010, Townshend, 2016). A story of sinister acts, mischievous plots and supernatural happenings taking place in Italy around the eponymous castle of Otranto, the novel "did much to bring the literature of horror into being" (Townshend, 2016, p. 23). Following that, a series of changes occurred to the genre of horror. From a revival in the $19^{\text {th }}$ century and an introduction of new themes such as science and mental illness, to a breakaway from the authority of the church in the early $20^{\text {th }}$ century, 
which made horror in a type of a "secular gothic" (Luckhurst, 2016, p. 115), horror fiction reached its peak in the $1970 \mathrm{~s}$, where it started to "experience a boom that would last throughout the following decade and remain, to the present day, unrivalled in the genre's history" (Hantke, 2016, p.159). And though the popularity of the genre declined towards the end of the twentieth century, it kept its place as an established genre among other types of literature.

With regard to the classification of the horror genre, Todorov (1975)'s account of the Fantastic as a literary genre has often been cited as the basis of classifying horror into types (e.g. Carroll, 1990; Hills, 2005; Prohászková, 2012). Todorov (1975) defined the Fantastic in terms of the perception (and interpretation) of the abnormal phenomena that befall the protagonists in the literary work: "there is an uncanny phenomenon which we can explain in two fashions, by types of natural causes and supernatural causes. The possibility of a hesitation between the two creates the fantastic effect" (p. 26). Whenever the line between the natural and the supernatural is blurry, the work belongs to the fantastic genre.

Todorov (1975) also refers to two other literary genres that are determined by attitudes to the abnormal phenomena:

[If] the laws of reality remain intact and permit an explanation of the phenomenon described, we say that the work belongs to another genre: the uncanny. If, on the contrary...new laws of nature must be entertained to account for the phenomena, we enter the genre of the marvelous. (Todorov, 1975, p. 41)

Hence, to sum up, the uncanny means the supernatural is explained while the marvellous means the supernatural is accepted. However, since the hesitation between the ways of explaining the supernatural (which characterizes the Fantastic) is part of the journey that leads to differentiating the Uncanny from the Marvellous, Todorov (1975) further distinguishes between two subgenres: the Fantastic-uncanny and the Fantastic-marvellous (p. 44). Both genres combine the fantastic element. There is confusion at the beginning about the nature of the supernatural phenomenon, before arriving at an interpretation; whether the supernatural is explained or accepted.

\section{REVIEW OF LITERATURE}

Several linguists have embarked upon the task of applying linguistic methods to the analysis of literature, most notably Fowler (1967), (1977), and Leech \& Short (2007). In his essay, Fowler (1967) paves the way for the operation of linguistic theory in the study of literature. The interest in the linguistic study of literature is viewed as "the end of a series of alterations in the interest of language students in texts of different character" (Fowler, 1967, p. 3). Form the focus on written language among $19^{\text {th }}$ century linguists to the counter-focus on spoken language in the $20^{\text {th }}$ century, "the assumption that all examples of language have a linguistic form susceptible of investigation" has become one of the tenets of linguistic study (Fowler, 1967, p. 10).

Fowler (1977) provides an eclectic model of "sentence-linguistics... [and] text linguistics" (p. x), drawing on Chomsky's transformational grammar and Halliday's functional grammar for studying prose fiction. Fowler analyses prose fiction as text, in terms of cohesion between sentences and then as discourse in terms of the author's "rhetorical stance" towards his characters and readers, i.e., point of view. It is also in this book that Fowler introduces his notion of 'mind-style.'Leech \& Short (2007), originally published in 1981 , is perhaps the most comprehensive and exhaustive account of literary stylistics. The book tackles all language levels and provides stylisticians with a thorough toolkit for the analysis of English fictional prose. The second edition includes two extra chapters on the latest developments in stylistic analysis. 
Simpson (2004) presents a guide to the practice of stylistics as well as tackling the latest developments in the discipline. Simpson divides his book into 3 sections, key concepts, development and exploration respectively. Simpson introduces the cognitive turn in stylistics and provides some important concepts in this new approach as well as an application of these concepts in the analysis of texts. Another seminal work on cognitive stylistics is the edited book of Semino \& Culpeper (2002). The book features multiple studies that employ cognitive stylistic approaches to the study of various types of literature; novels, plays or poetry. For example, Culpeper (2002) provides a cognitive stylistic approach to characterization and draws on van Dijk and Kintsch (1983)'s model of text comprehension (p. 257). Semino (2002) also undertakes a cognitive stylistic approach to mind style in fiction. Semino gives the notion of Fowler's mind style a new cognitive gloss and draws on multiple cognitive theories including schema theory, cognitive metaphor theory and blending theory.

Studies that apply linguistic analysis to horror favor the earlier versions of the genre, i.e., gothic fiction. For example, Aguirre (2014) studies formulaic patterns in gothic fiction, taking The Necromancer (1794) as a model. He identifies the lexical fields that accompany the node-field 'with horror' which, together, make up the formulaic patterns in the novel and then studies them syntactically and phonologically. Jones (2010) also conducts a corpusstylistic analysis on gothic fiction. The study uses ten works of gothic fiction that are representative of the century from 1800 to 1900. The corpus underwent a keyword and frequency analysis along with an analysis of collocations and clusters. After the quantitative analysis, Jones provides a qualitative analysis of the results, giving some observations on the recurring words and their stylistic function in the gothic texts.

Ferguson (2004) explores Bram Stoker's employment of language variation in his seminal novel Dracula (1897). Though not strictly adopting linguistic techniques in her treatment of the text, Ferguson (2004) highlights the role of sociolinguistics in antagonizing Dracula. As a foreigner to the English community (both as a non-Englishman and a vampire), Dracula is very keen to speak a perfect and impeccable version of English in order to merge into society. However, faced by nonstandard language of the common people of England, it becomes clear that "the linguistic deviations - whether of syntax, diction, or accent... are constitutive of a fundamentally human network of communication from which the vampire is excluded" (p. 241).

Moving from gothic fiction, some studies focused on modern and contemporary horror. For example, Peer \& Graf (2002) conduct a cognitive stylistic analysis of spatial language development of Stephen King's novel IT (1986). They investigate whether King pays attention to cognitive abilities of his characters through analyzing their use of spatial language first as children and then when they meet again as adults and how meeting the entity IT had a say in their cognitive perception of space. Landais (2016), on the other hand, investigates the problems of translating fear in modern horror fiction into French. Landais analyzes the translation of excerpts from short stories and novels by modern horror writers such as Stephen King and James Cooper.

Anderson (2017) is perhaps the most recent example of applying linguistic analysis to modern horror fiction. Anderson dedicates his book to the study of Stephen King's works. The book consists of 22 chapters, with each chapter viewing one of King's works (novels, short stories or novellas) from a linguistic angle. Anderson (2017) relies on a mix of postmodern theories, including "Marxist, feminist and psychoanalytical criticism" and the linguistic theories of J. L. Austin, John Searle, and Ferdinand de Saussure (p. 7). For example, in his treatment of King's The Shining (pp. 35-43), Anderson (2017) applies a deconstructive view of language in the novel, where "the shine" is considered a "prelinguistic ability that allows him to understand with his intuition and his precognitive senses, which don't rely on the accuracy of words" (p. 42). 
In her study of deviance in contemporary crime fiction, Gregoriou (2007) dedicates a portion of her work to its linguistic deviance. She conducts a cognitive stylistic analysis of three portrayals of criminal minds, drawn from novels from the 1990s. Though belonging to the genre of crime fiction, the deviance and abnormality of the criminal minds can fit into the category of the uncanny in Todorov (1975)'s taxonomy. Gregoriou (2007) explores the criminal mind using the notions of mind-style and point of view, and she argues (and proves) that since our minds put limits on the linguistic structures we utter, "the way that the criminal mind is linguistically portrayed is closely tied to the way the criminals are believed to conceptualise their lives and actions" (p. 78). Sazonova (2018) conducts a comparative analysis of English and Ukrainian texts of horror discourse. Sazonova explores "the textual actualization of fear" (p. 21) through a pragmatic/semantic analysis of the names given to monsters in horror texts of H.P. Lovecraft and some Ukrainian authors. Sazonova argues that different nomination strategies of monstrosities are used in horror texts to evoke diverse senses of fear, either fear-awe or fear-disgust.

\section{OBJECTIVES OF THE STUDY}

Against this background, the present paper contributes to the current literature on horror fiction because contemporary horror has been academically understudied. The idea is that, as an already established (literary) genre, horror must normally bear "the semantic and syntactic features that create the communicative situation" (Miall, 2002, p. 325). Hence, the aim is to pinpoint some of the features of the horror language that are part and parcel of the genre, using a cognitive stylistic approach.

\section{THEORETICAL FRAMEWORK}

The theoretical framework adopted here is an eclectic one, primarily designed in an attempt to elicit the workings of language in the mind. Since this is an analysis of written horror fiction, producing the effect of horror lies heavily on how the author uses the text to play with the readers' mentality, hence horrifying them. The framework is a text-based cognitive stylistic one. Cognitive stylistics is viewed as a development in the discipline (Simpson, 2004, Leech \& Short, 2007) and is known as a 'cognitive turn,' as mentioned earlier, in which stylistics "is moving to integrate linguistic, psychological and more literary approaches" (Leech \& Short, 2007, p. 295).

According to Semino \& Culpeper (2002), cognitive stylistics is the discipline that combines "the kind of explicit, rigorous and detailed linguistic analysis of literary texts that is typical of the stylistics tradition with a systematic and theoretically informed consideration of the cognitive structures and processes that underlie the production and reception of language (p. ix). Hence, in addition to the "cognitive structures and processes" of language production and reception, a typical text-based approach to literary language is also employed.

\subsection{Cognitive Considerations}

The cognitive considerations chosen are primarily selected because they use a cognitive gloss to address central issues characteristic of literary language.

\subsubsection{Conceptual Metaphor Theory and Blending Theory}

Conceptual Metaphor and Blending theories are closely related in that they both involve mapping properties of cognitive structures unto others. Developed by Lakoff \& Johnson (1980), Conceptual Metaphor Theory has freed the phenomenon of metaphors from its literary shackles and cast a new light on it as a cognitive feature inherent in our minds, and experiential in nature. Conceptual metaphors are "pervasive in everyday life, not just in language but in thought and action. Our ordinary conceptual system, in terms of which we both think and act, is fundamentally metaphorical in nature" (p. 3). Such new light relates 
metaphors to cognition and discerns the workings of metaphors in our minds. They argue that these metaphors are so entrenched in our conceptual system that they are hardly recognizable, they call them "conventional metaphor." Some of the most famous examples of everyday conceptual metaphors that are subconsciously embedded in our thought include LOVE IS A JOURNEY, ARGUMENT IS WAR and TIME IS MONEY, where mappings from concrete source domains (journey, war and money) are conferred unto the more abstracts target domains (love, argument and time). Hence, directionality is important in metaphors since the concrete concepts which "are more clearly delineated in our experience" (Lakoff \& Johnson, 1980, p. 112) help make abstract concepts more comprehensible.

Besides metaphors that structure our conceptual system, Lakoff and Johnson (1980) also point to metaphors that are "imaginative and creative" (p. 139), those which involve mappings between unconventional domains, created in a specific situation, for a specific purpose. Furthermore, Gibbons and Whiteley (2018) argue that metaphors are better viewed "as a cline in terms of their visibility. Visible metaphors are realised linguistically... Invisible metaphors... require more creative, interpretive work from readers" (p. 209; bold in original). It is this type of unconventional metaphors that is intentionally exploited by authors of literary texts - especially horror, fantastic, texts - to create a mental image in the minds of their readers of incomprehensible situations or entities for their own specific purposes and governed by thematic constrictions.

However, unlike conventional metaphors, and because of their innovative nature, the mapped properties from source to target domains are selective, rather than unidirectionally collective. One way to explain the selectiveness in unconventional metaphors is to resort to Conceptual Blending or Conceptual Integration Theory (Birdsell, 2014; Gibbons \& Whiteley, 2018).

Blending theory was founded in 1993 and has reached its full form in Fauconnier \& Turner (2002). Blending or Conceptual Integration theory is

a basic mental operation that leads to new meaning... the essence of the operation is to construct a partial match between two input mental spaces, to project selectively from those inputs into a novel 'blended' mental space, which then dynamically develops emergent structure (Fauconnier \& Turner, 2003, pp. 57-8; emphasis added).

Hence, in Blending theory, domains are termed 'mental spaces,' which are "small conceptual packets constructed as we think and talk, for purpose of local understanding and action" (Fauconnier \& Turner, 2003, p. 58). Blending happens when certain features are selectively projected from two or more input spaces into another blended space. There is a generic mental space which "maps onto each of the inputs and contains what the inputs have in common" (Turner, 2007, p. 378). The following diagram sums up the most important properties characteristic of the conceptual integration process: 


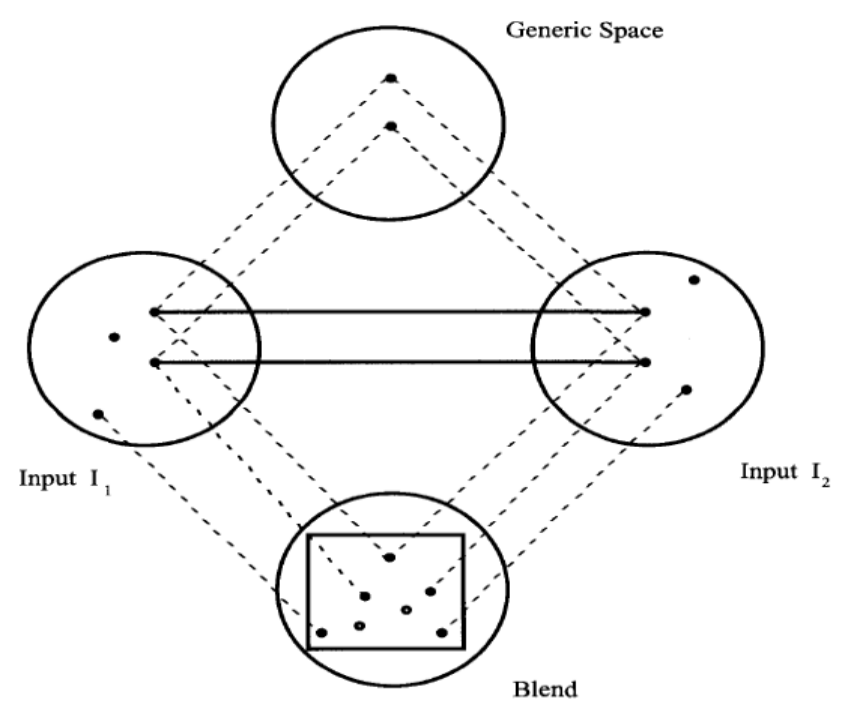

Fig. 1 Basic diagram for the central features of conceptual integration (adapted from Fauconnier \& Turner, 2002, p. 46)

Another integral feature of the blending process is the emergent structure (the square in the blended space) which involves the features mapped from the input spaces combined. According to Turner (2007), the steps of generating the emergent structure are as follows,

(i) Composition of projections from the inputs: blending can compose elements from the input spaces to provide relations that do not exist in the separate inputs. (ii) Completion based on independently recruited frames and scenarios: we rarely realize the extent of background knowledge and structure that we bring into a blend unconsciously. Blends recruit great ranges of such background meaning. Pattern completion is the most basic kind of recruitment. (iii) Elaboration: we elaborate blends by treating them as simulations and running them imaginatively according to the principles that have been established for the blend. (p. 379)

Hence, it is evident why both theories are integral to each other. First, as Freeman (2007) puts it, both theories are closely related because "all metaphors at some stage in their creation involve blending" (p. 1186). Second, blending happens to better explain the class of metaphors that involve more cognitive work than that required for the conventional entrenched ones. Whereas "domain mapping of conceptual metaphor theory fails to explain the metaphorical interpretation... blending theory can account for such an inference through emergent structure" (Birdsell, 2014, p. 83). Blending is a fine theorization of human creativity when it comes to using language, where the emergent structure gives space for the brainchild of human creative thought (Freeman, 2007).

\subsubsection{Schema Theory}

Another important cognitive consideration is Schema Theory. According to Simpson (2004), schema theory "has provided an insightful method for accounting for how we draw on stores of knowledge, and how we make conceptual transfers between these stores" (p. 89). It is an integral notion to cognitive stylistics, which is borrowed from psychology and artificial intelligence. A schema is defined as

a cognitive structure which provides information about our understanding of generic entities, events and situations, and in so doing helps to scaffold our mental understanding of the world. A schema (sometimes known as a 'frame,' 'script' or 'scenario') contains common default information which aids comprehension by 
allowing a reader to extrapolate details which are either not mentioned at all in a text or which are not fully specified. (Emmott et al, 2014, p. 268)

The pioneer in this area is Cook (1994)'s seminal work on discourse schemata, in which he linked the notions of defamiliarization and foregrounding to that of schema. Cook (1994) points out that defamiliarization is inherently "reader-dependent" since for the process to be successful it has to "make strange" what is normal to the readers. Hence, defamiliarization implies "a relationship between a reader and an object of perception (even if that object of perception is another text, or the language itself)" (p. 207). He further links the notions of foregrounding and deviation to that of schema and criticizes previous approaches for attributing the quality of defamiliarization to texts rather discourses.

Though the use of schema theory is not new to linguistic models (e.g. in discourse analysis), Cook (1994) rejects the view of schemata as rigid or "static representations brought to bear upon the text... [a view which neglects] the ways in which certain texts may rebound upon the schema used to interpret them, leaving those schemata radically altered" (p.181). He also posits the theory of defamiliarization as a gate to a theory that combines literary effect and reader's mind. Hence, he proposes a theory of 'discourse deviation' that rests upon defining literariness as "a dynamic interaction between linguistic and text-structural form on the one hand, and schematic representations of the world on the other, whose overall result is to bring about a change in the schemata of the reader" (P. 182).

Cook (1994) puts discourse and schemata in a cause-effect relationship, where the existence of the former is closely tied to causing an effect on the latter. Since schemata are basically what constitutes our understanding of the world, it makes sense that discourses rely heavily on them. In his taxonomy of discourse effects on schemata, shown below in Fig. 2, Cook (1994) identifies three effects - namely schema reinforcing, preserving and disrupting or refreshing - and views the literariness of literary works as basically a matter of refreshing schemata in readers' minds. By the same token, Emmott et al. (2014) further explains that schema is important in cognitive analyses of literature because "special effects' can be created by an author through the subversion, exploitation, alteration, or violation of a reader's schema knowledge" (p. 268).

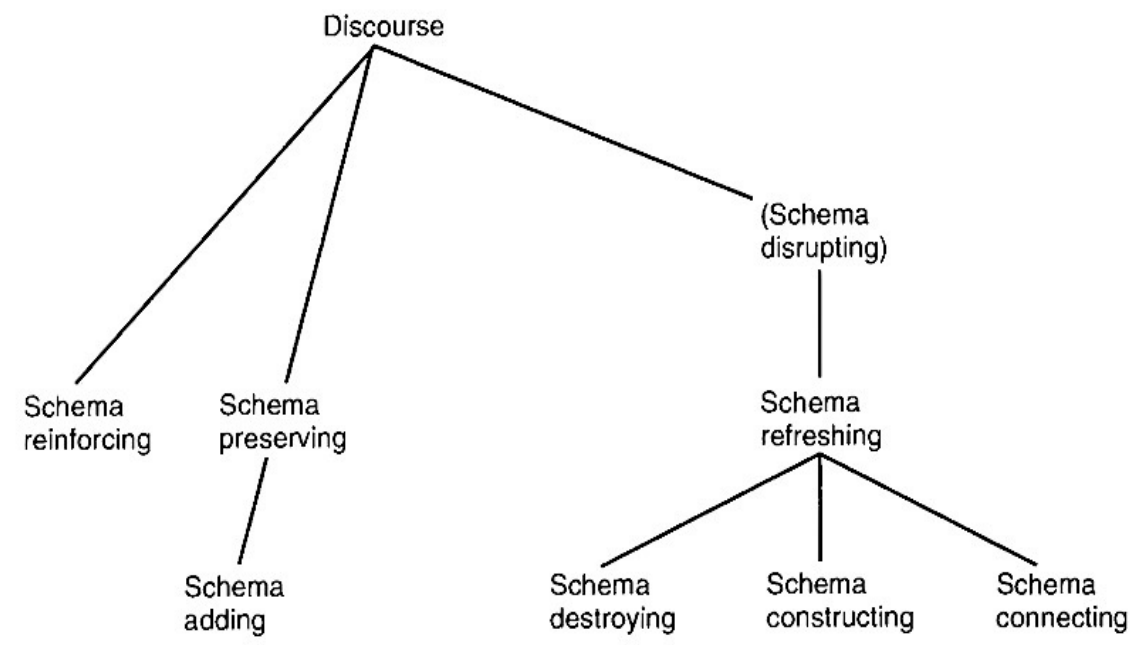

Fig.2 Discourse effects on schemata (adapted from Cook, 1994, p. 191) 
Schema theory is thus most apt to the analysis of horror fiction because horror fiction relies on a non-indexical engagement with the world (Reyes, 2016), hence, working on the disruption of normal schemata is a must. As Simpson (2004) puts it, "the primary function of certain kinds of discourse is to effect a change in the schemata of their readers, and preeminent among these is literary discourse which often works to disrupt and then refresh schemata" (p. 90). Thus, in literary discourse, "[a] text world is a 'total construct' which requires for its understanding memory and imagination, rather than direct perception" (p. 91).

\subsection{Stylistic Analysis}

The "rigorous and detailed linguistic analysis of literary texts," as Semino \& Culpeper (2002) call it, or the text-based approach makes use of the linguistic approach to literature developed by Fowler (1977), (1986), Leech \& Short (2007) and Simpson (2004), who draw primarily on Halliday's (2004) functional grammar for their tools of analysis. As put forward by Fowler, (1967), the notion of style "may be said to reside in the manipulation of variables in the structure of a language, or in the selection of optional or 'latent' features" (p. 15). Hence, stylistics is defined as "the way in which language is used in a given context, by a given person, for a given purpose, and so on" (Leech \& Short, 2007, p. 9), while a narrower scope defines literary stylistics as the exploration of "how language serves a particular artistic function" (Leech \& Short, 2007, p. 12).

It is important to note when approaching literary texts that "every analysis of style... is an attempt to find the artistic principle underlying a writer's choice of language. All writers, and for that matter, all texts, have individual qualities" (Leech \& Short, 2007, p. 60). Therefore, it is the text that guides the linguist not the other way around. However, it is important to have a "checklist of features which may or may not be significant in a given text" (Leech \& Short, 2007, p. 60), and which covers the basic levels of language analysis. This tentative checklist of linguistic tools works on the lexical, syntactical, morphological, graphological and cohesion levels (Leech \& Short, 2007, p. 61-67). The linguistic checklist includes, among other things, the investigation of:

- Nouns in terms of concreteness/abstractness, complexity and abundance. The same goes for adjectives, are they evaluative, attributive, predicative or not.

- Verbs' semantic meanings (in terms of transitivity patterns).

- Sentence types in terms of structure and complexity.

- Noteworthy morphological categories.

- The cohesive ties that hold the text together and their contribution to its artistic effect.

Other linguistic analytical tools that connect stylistics to cognition are Fowler (1986)'s notion of underlexicalization and overlexicalization. According to Fowler (1986), lexicalization is the way we "encode ideas or experience" in which "the lexis of a person, or of a discourse, or of a society, can be regarded as mapping the conceptual repertoire of the person" (p. 151). The processes of under- and over-lexicalization are effects of deviating from the norm. Underlexicalization is "lack of a term or of a set of terms...[suggesting that] such gaps, in an individual's lexical repertoire, mean that the individual does not have access to the concepts concerned, or has difficulty of access" (p. 152). On the other hand, overlexicalization is "the availability, or the use, of a profusion of terms for an object or concept" (p. 154).

Semino (2007) suggests that combining Fowler (1986)'s notions of under- and overlexicalization and that of 'schema' can augment the analysis of narratives. According to Schema Theory, "comprehension requires that the comprehender both possesses and activates the schema or schemata that are appropriate to the text or experience they are involved with" (Semino, 2007, p. 157). Accordingly, instances of underlexicalization can be ascribed to lack 
of relevant schema, either because of medical impairment, childish point of view, or the description of newfangled concepts.

Additionally, according to Fowler (1977), in fictional writing "the linguistics of discourse applies most naturally to point of view, the author's rhetorical stance towards his narrator, towards his characters (and other elements of content), towards his assumed reader" (p. 52). This point of view is termed by Fowler as 'mind-style.' In the context of prose fiction, mind-style is the perspective of the voices in the work of literature and their representation of reality: "the I-figure narrating, the characters, the implied author who controls both narrator and characters, and who often takes a line on them" (p. 76). Hence, simply stated, mind-style "is a realization of a narrative point of view" (Leech \& Short, 2007, p. 151).

Fowler (1977) differentiates between internal and external points of view or mindstyles. Since a novelist "can always be sure about any state which he attributes to his characters, since he is absolutely in control of their feelings" (p. 92), providing an internal or external point of view is purely a matter of stylistically-driven choice on part of the author. The mind-style can be recognized through its

distinctive linguistic presentation of an individual mental self. A mind-style may analyse a character's mental life more or less radically; may be concerned with relatively superficial or relatively fundamental aspects of the mind; may seek to dramatize the order and structure of conscious thoughts, or just present the topics on which a character reflects, or display preoccupations, prejudices, perspectives and values. (p. 103)

The external point of view is usually characterized by "words of estrangement," like modals and words like seem, appear which the author uses to alienate himself from the text, "as if the narrator and the reader have no unnatural advantage of insight or foreknowledge over an ordinary inquisitive observer" (p. 95). On the other hand, the internal point of view is characterized by plenty of verba sentiendi or words of feelings which open to us "characters' states of mind, reactions and motives, either by narrative report (and judgement, inescapably), by telling of what in real life would be hidden from an observer" (p. 89).

\section{A COGNITIVE STYLISTIC ANALYSIS OF HORROR}

As previously mentioned, the period of the 1970s represents the peak of contemporary horror literature. Following is an analysis of an excerpt from William Peter Blatty's famous novel The Exorcist (1971), one of the most iconic horror texts of this decade. Blatty received his education in a Jesuit preparatory school and then became a student at Georgetown University and based his novel on the real incident of a 14-year-old boy who was possessed in Maryland (Backer, 2015, p. 326). The Exorcist is about the strange phenomena that befall 12-year-old Regan MacNeil, the daughter of a famous actress and the journey of trying to diagnose her until it is set that she was possessed by a diabolical entity. The novel belongs to the Fantastic-marvellous genre, which is "the class of narratives that are presented as fantastic and that end with an acceptance of the supernatural" (Todorov, 1975, p. 52).

The followings excerpt is the final scene of chapter 3, showing the 12-year-old Regan who is now possessed with a diabolical entity and is acting accordingly. The present brief qualitative analysis is basically aimed at discerning how supernatural (evil) entities are textually and cognitively represented in contrast to the (human) characters surrounding them. 
Gliding spiderlike, rapidly, close behind Sharon, her body arched backward in a bow with her head almost touching her feet, was Regan, her tongue flicking quickly in and out of her mouth while she hissed sibilantly like a serpent. (1)

"Sharon?" (2) Chris said numbly, still staring at Regan. (3)

Sharon stopped. (4) So did Regan. (5) Sharon turned and saw nothing. (6) And then screamed as she felt Regan's tongue snaking out at her ankle. (7)

Chris whitened. (8) "Call that doctor and get him out of bed! (9) Get him now!” (10)

Wherever Sharon moved, Regan would follow. (11)

(Blatty, 1971, p. 135)

First and foremost, the point of view in the previous excerpt is clearly an external one. Though being the creator of such characters (supernatural and human), the writer opts out of being an omniscient author, and chooses the position, in the words of Fowler (1977), of an "unprivileged observer." There are no verba sentiendi. All the adverbs and verbs used are palpable and descriptive rather than reflective. Even the verb felt in (6) refers to the tangible, visible, effect of Regan's tongue on Sharon's leg. Additionally, the similes used by the author in an attempt to explain what Regan has become add to the horrific effect that the realization of this creature has. This is because the author, in spite of creating the character, alienates himself from the text, leaving the reflection on such incident to the reader.

On the lexical level, this excerpt has a low number of nouns. Aside from the proper nouns (Regan, Sharon and Chris), the rest of the nouns are mainly concrete, and mostly dedicated to description of the possessed Regan. As seen in (1), the nouns include, body, head, feet, tongue and mouth. This representation of a dismantled Regan is a disruption (destruction) of an existent schema and construction of a new one for a possessed person. Blatty employs a strategy called "undercoding, expressed by underlexicalization," where the lack of a particular lexical item from an individual's repertoire suggests that that individual lacks the relevant concept (Fowler, 1986, p. 152). However, it is an underlexicalization in disguise, since it is compensated by overlexcalization of possessed Regan. The foregrounding of Regan's body parts forces in the reader's mind the image of her metamorphosis from a whole human being into an indecipherable creature that has to be decoded and perceived in pieces in order to be made sense of.

The metaphors Blatty uses here are all visible and equally dismantled, irrelevant, and perplexing to the readers, contributing to forming the mental image of possessed Regan in their minds. Blatty uses visible metaphors (realized linguistically by the suffix -like or the preposition like), primarily because their schema is already disrupted by the realization that a little girl is possessed with a demon, hence, visible metaphors would help them make sense of the new disrupted schema.

In the metaphors used to describe Regan, plenty of mental spaces are activated. Regan glides spiderlike, arches backward in a bow and hisses like a serpent with her tongue flicking quickly in and out of her mouth. 


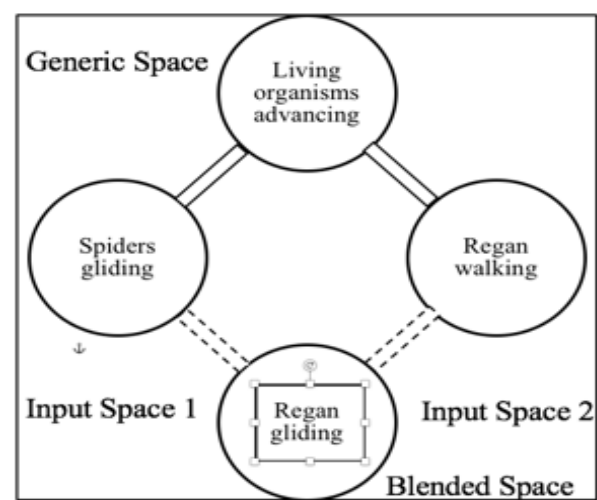

Fig. 3 Blending in Metaphor 1

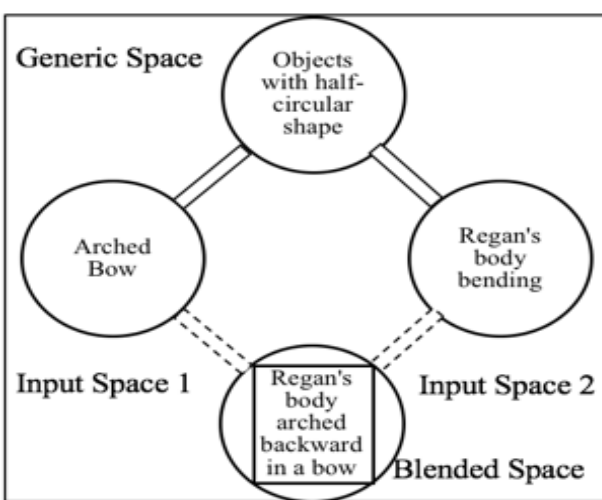

Fig. 4 Blending in Metaphor 2

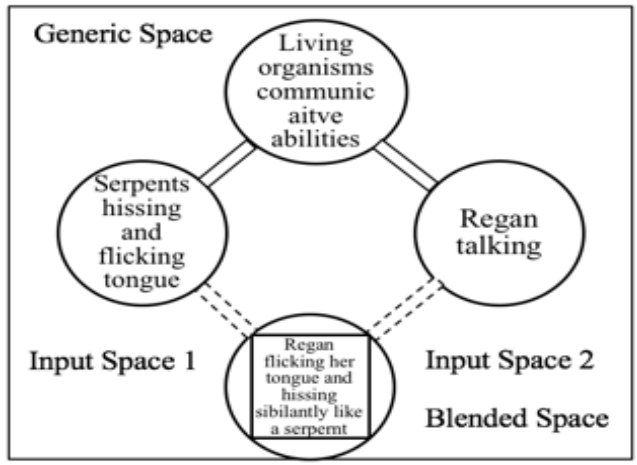

Fig. 5 Blending in Metaphor 3

In each of the metaphors described above, conceptual blending takes place between very unconventional mental spaces. The mental spaces activated are insects (spiders), archery weapons (archery bows) and reptiles (snakes). Though the mental space activated encompass whatever associated with the thing described, each of them is blended, via selective projection, with an aspect of the possessed Regan. The contrasting and irrelevant spaces (or domains, in conceptual metaphor theory terms) help readers construct a new (and terrifying) schema of possessed humans. Regan has left the human form and turned into an incomprehensible creature that requires similes and metaphors to be understood.

Another layer of blending further happens on the level of emergent structures, where each emergent structure contributes to completing the mental image of the possessed Regan, as evident in the figure below.

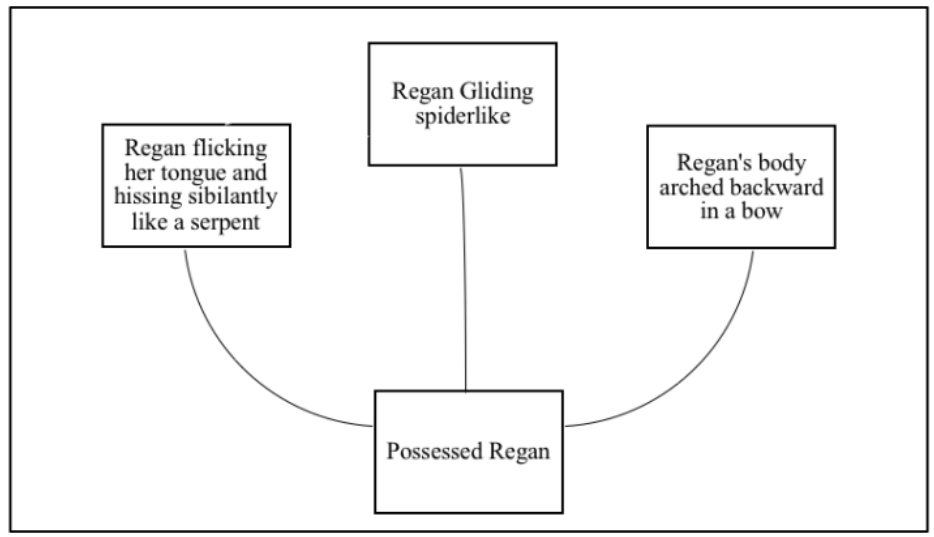

Fig. 6 Blending of Emergent Structures 
On the morphological level, almost all of the adjectives in this excerpt are also dedicated to the description of possessed Regan. What is striking about the adjectives is that they are participial in form; Gliding, arched, touching, flicking. The choice to present these adjectives in the participle form is revealing. Participles are often viewed as a tenseless and imperfect verb form, a verb form that bears no information about time. Attributing timelessness to possessed Regan has two stylistic, horrific, effects. First, it asserts its supernatural nature, that it no longer obeys, nor is it defined by human's time. The second effect is in the scene itself. Though semantically implying movement (enhanced by the adverbs rapidly and quickly), the imperfect form gives the feeling that this action is ongoing (forever), with no start nor end points in time, again, behind our scope as humans.

On the syntactic level, there is an immediate striking contrast between sentence (1) and the rest from (2) through (11). Sentence (1) is a lengthy complex sentence. A sentence's complexity, as Leech \& Short (2007) put it, "gives and withholds information, subordinates some ideas to others more important, coordinates those of equal weight, and ties into a neat package as many suggestions, modifiers, and asides as the mind can attend in one stretch" ( $\mathrm{p}$. 176). And this is what Blatty did in the first sentence. The complex nature of the sentence allowed Batty to embed - in subordinate non-finite clauses -as much information (modifiers) as he can about this diabolical entity with the aim of helping readers construct the new schemata for possessed humans. Additionally, Blatty uses a "periodic sentence structure" (Leech \& Short, 2007). This structure is characterized by saving the main clause to the very end, with the subordinate clauses being called anticipatory constituents if they precede the main clause, and trailing constituents if they follow it (p. 181-2). So, in this light, sentence (1) can be analyzed as follows:

Anticipatory constituents

Gliding spiderlike, rapidly, close behind Sharon, her body arched backward in a bow with her head almost touching her feet,

\section{Main clause Trailing constituents}

\begin{tabular}{ll} 
Regan & \multicolumn{1}{c}{ her tongue flicking } \\
& quickly in and out of her \\
mouth while she hissed \\
sibilantly like a serpent
\end{tabular}

The anticipatory constituents add "an element of suspense into syntax...an anticipatory constituent must therefore be held in the memory until the major constituent of which it is a part has been interpreted" (Leech \& Short, 2007, p. 182). Hence, when faced with these subordinate clauses, readers have to burden their memory with these horrific descriptions until they reach the main clause, which is a copular inversion (to add to the abnormality of the possessed Regan). Even though This is Leech \& Short (2007) observe that periodic sentences "have a dramatic quality: they combine the principle of climax with the principle of subordination, and so progress from a build-up tension to a final climatic point of resolution" (p. 182), Blatty adds a list of trailing (and disturbing) constituents still to the main clause, making the cognitive burden even heavier, instead of giving them the relief, or resolution, of decoding this complex structure.

Directly after sentence (1), sentences (2-11) become less complex and much shorter:

$$
\text { "Sharon?" (2) }
$$

Sharon stopped. (4)

So did Regan. (5)

Sharon turned and saw nothing. (6) 
Although in varied contexts, sentence brevity has been associated in the literature with an authoritative and brusque tone (Fowler, 1977), and sometimes with childlike naivety (Leech \& Short, 2007), in the present context, the simplicity of these sentences reflect the tension, the horror, that arose as a result of the human characters' realization of a supernatural entity in front of which they are helpless. Furthermore, the striking contrast between the first sentences and those that follow places the reader right in the middle of this horrific realization. After the memory burden of the complex sentence, the sudden brevity of the following sentences creates a textual silence that resounds in the readers' minds and gives them time to process the horror of what they have just encountered.

In terms of transitivity patterns in the excerpt, the verbs' distribution is as follows:

$\begin{array}{llll} & \text { Participant } & \text { Process } & \text { Process type } \\ 1 & \text { Regan } & \text { Was } & \text { Relational } \\ 2 & \text { She [Regan] } & \text { Hissed } & \text { Behavioral } \\ 3 & \text { Chris } & \text { Said [numbly] } & \text { Verbal } \\ 4 & \text { Sharon } & \text { Stopped } & \text { Material } \\ 5 & \text { Regan } & \text { Did [stop] } & \text { Material } \\ 6 & \text { Sharon } & \text { Turned } & \text { Material } \\ 7 & \text { [Sharon] } & \text { Screamed } & \text { Behavioral } \\ 8 & \text { She [Sharon] } & \text { Felt } & \text { Mental } \\ 9 & \text { Chris } & \text { Whitened } & \text { Material } \\ 10 & \text { Sharon } & \text { Moved } & \text { Material } \\ 11 & \text { Regan } & \text { Follow } & \text { Material }\end{array}$

As can be seen, there is not much action in this scene, when it comes to the characters involved. Even though much of the description attributed to the possessed Regan involve movement (e.g. gliding rapidly), this is only semantically achieved, while syntactically, it remains in the realm of attributing to Regan these descriptions instead of actually doing them. Hence the verb types involved provide no syntactic progression. Even when the process types are material (e.g. 4-5), the action is one of stopping rather than moving. This stillness, coupled with the brief syntactic structure, which pervades the excerpt, heightens the tension of the scene and adds to its horrific effect.

Cohesion also has its role in creating horror in this excerpt. In sentence (1), cataphoric reference is used as a means of creating suspense

Gliding spiderlike, rapidly, close behind Sharon, her body arched backward in a bow with her head almost touching her feet, was Regan.

There is also lexical reiteration in the form of direct repetition. There is a tendency to repeat proper names, Sharon ( $x 4$ ), instead of pronominal substitution: 'Sharon stopped. (4) So did Regan. (5) Sharon turned and saw nothing.' Though maybe used in order to avoid confusion (between Regan and Sharon), the effect of such repetition in a short span of sentences increases the tension and alerts readers that something is wrong. Additionally, the synonyms rapidly and quickly in (1) aggravate the bizarre movement of the possessed Regan. A point should be made about the phonological aspect of the following clause: "while she 
hissed sibilantly like a serpent.' In addition to using the onomatopoeic word hiss, the consonance achieved by the repetition of the /s/ phoneme, the voiceless alveolar sibilant, paints a very vivid auditory (and horrific) image in the minds of readers.

\section{CONCLUSION}

This paper has attempted to demonstrate that the performative power of horror texts is mainly a matter of how language works in the minds of readers. As a genre whose primary discourse effect is schema-disruption, it goes without saying that such disruption is equally reflected in the language used. It has been shown how disruption occurs on the lexical and syntactic levels, whereby the human mental capacity of blending is unconventionally exploited to force a mental image in the minds of readers of an otherwise impossible reality. Additionally, highly complex syntax is a way that allows horror writers to embed as much information as they can to try and match the horrific reality they are describing. In contrast, the sudden brevity of syntax - when compared to its complexity - matches the silent tension and confusion happening in the minds of readers after coming to grips with the supernatural entities they have encountered.

Finally, it is needless to say that there are some limitations to be pointed out regarding this study. It is worthy of noting that the results are only representative of the excerpt in question and further explorations of diverse horror texts will yield more comprehensive results on multiple levels of analysis. Additionally, a reader-response analysis can enrich the results of investigating the linguistic features of horror fiction by involving the actual reader in the process of analysis rather than the implied or ideal one.

\section{References}

Aguirre, M. (2014). 'Thrilled with chilly horror': A formulaic pattern in gothic fiction. Studia Anglica Posnaniensia. 49(2), 105-123. https://doi.org/10.2478/stap-2014-0010

Anderson, J. A. (2017). The linguistics of Stephen King. Layered language and meaning in the fiction. McFarland \& Company, Inc.

Backer, R. (2015). Classic horror films and the literature that inspired them. McFarland \& Company, Inc.

Bawarshi, A. S., \& Reiff, M.J. (2010). Genre: an Introduction to History, Theory, Research, and Pedagogy. Parlor Press.

Birdsell, B. J. (2014). Fauconnier's theory of mental spaces and conceptual blending. In J. Littlemore \& J. R. Taylor (Eds), The bloomsbury companion to cognitive linguistics (pp. 72-90). Bloomsbury Publishing.

Blatty, W. P. (1971). The Exorcist. HarperCollins Publishers.

Carroll, N. (1990). The Philosophy of horror: Or paradoxes of the heart. Routledge.

Chandler, D. (1997). An Introduction to genre theory. http://www.aber.ac.uk/media/Documents/intgenre/chandler_genre theory.pdf [2018, September 3]

Cook, G. (1994). Discourse and literature: The interplay of form and mind. Oxford University Press

Dixon, W. W. (2010). A History of horror. Rutgers University Press. 
Emmott, C., Alexander, M. \& Marszalek, A. (2014). Schema theory in stylistics. In M. Burke (Ed.). The Routledge handbook of stylistics (pp. 268-83). Routledge.

Fauconnier, G. \& Turner, M. (2002). The way we think. Conceptual blending and the mind's hidden complexities. Basic Books.

Ferguson, C. (2004). Nonstandard language and the cultural stakes of Stoker's "Dracula". ELH. 71(1), 229-249. https://doi.org/10.1353/elh.2004.0015

Fowler, R. (1967). Linguistic theory and the study of literature. In Fowler, R. (Ed.) Essays on style and language: Linguistic and critical approaches to literary style (pp. 1-28). Routledge and Kegan Paul.

Fowler, R. (1977). Linguistics and the novel. Metheun.

Fowler, R. (1986). Linguistic criticism. Oxford University Press.

Fowler, R. (1997). 'Literature as discourse'. In: Newton K.M. (Ed.) Twentieth-century literary theory (pp. 77-82). Palgrave.

Freeman, M.H. (2007). Cognitive linguistic approaches to literary studies: State of the art in cognitive poetics. In D. Geeraerts, \& H. Cuyckens (Eds.), The Oxford handbook of cognitive linguistics (pp. 1175-1202). Oxford University Press.

Gee, p. (1999). An Introduction to discourse analysis: Theory and method. Routledge.

Gibbons, A. \& Whiteley, S. (2018). Contemporary stylistics. Language, cognition, interpretation. Edinburgh University Press.

Gregoriou, C. (2007) Deviance in contemporary crime fiction. Palgrave Macmillan.

Hall, K. (2000). Performativity. Journal of Linguistic Anthropology. 9(1-2), pp. 184-187. https://doi.org/10.1525/jlin.1999.9.1-2.184

Halliday, M.A.K. (1978). Language as social semiotic: The social interpretation of language and meaning. Edward Arnold.

Halliday, M.A.K. (2004). An Introduction to functional grammar. (3rd edition). Arnold.

Hills, M. (2005) Pleasures of horror. Bloomsbury Publishing.

Hantke, S. (2016). The Rise of popular horror, 1971-2000. In Reyes, X. A. (Ed), Horror: A literary history (pp. 159-187). The British Library.

Jeffries, L., \& McIntyre, D. (2010). Stylistics. Cambridge University Press.

Jones, D. (2002). Horror. A thematic history in fiction and film. Arnold.

Jones, S. (2010). Exploring gothic fiction: A corpus-based analysis. (MSc dissertation, University of Edinburgh, Edinburgh, UK). https://www.era.lib.ed.ac.uk/handle/1842/5351

Lakoff, G., \& Johnson, M. (1980). Metaphors we live by. University of Chicago Press.

Landais, C. (2016). Challenges and strategies for analysing the translation of fear in horror fiction. Literary Imagination. 18(3), 242-254. https://doi.org/10.1093/litimag/imw018 


\section{Language Performativity and Horror Fiction: A Cognitive Stylistic Approach}

Leech, G. N., \& Short, M. (2007). Style in fiction: A linguistic introduction to English fictional prose (2nd ed.). Pearson Longman.

Luckhurst, R. (2016). Transitions: From victorian gothic to modern horror, 1880-1932. In Reyes, X. A. (Ed), Horror: A literary history (pp. 103-129). The British Library.

Miall, D. S. (2002). Literary discourse. In Art Graesser, Morton Ann Gernsbacher, \& Susan R. Goldman, (Eds.) Handbook of discourse processes. (pp. 321-355). Lawrence Erlbaum Associates.

Peer, W. V. \& Graf, E. (2002). Between the lines. Spatial language and its developmental representation in Stephen King's IT. In E., Semino, \& J., Culpeper (Eds.), Cognitive stylistics: Language and cognition in text analysis (pp. 123-152). John Benjamins.

Prohászková, V. (2012). The genre of horror. American International Journal of Contemporary Research. 2(4), 132-142.

Reyes, X. A. (2016). Introduction: What, why and when is horror fiction? In Reyes, X. A. (Ed), Horror: A literary history (pp. 7-17). The British Library.

Sazonova, Y. (2018). Pragmatic potential of the nomination of the subject-source of fear (a monstrosity) in texts of horror discourse. Verbum. 8, 20-28. https://doi.org/10.15388/Verb.2017.8.11323

Semino, E. (2002). Between the lines. A cognitive stylistic approach to mind style in narrative fiction. In E., Semino, \& J., Culpeper (Eds.), Cognitive stylistics: Language and cognition in text analysis (pp. 95-122). John Benjamins.

Semino, E. \& Culpeper, J. (Eds.). (2002). Cognitive stylistics: Language and cognition in text analysis. John Benjamins.

Semino, E. (2007). Mind Style 25 years on. Style. 41(2), 153-203.

Simpson, P. (2004). Stylistics: A resource book for students. Routledge.

Stockwell, P. (2005). On cognitive poetics and stylistics. In H. Veivo, B. Pettersson and M. Polvinen (Eds.). Cognition and literary interpretation in practice (pp. 267-82). University of Helsinki Press.

Todorov, T. (1975). The fantastic. (R. Howard, Trans). Cornell University Press.

Toolan, M. (2014). The theory and philosophy of stylistics. In P. Stockwell \& S. Whiteley (Eds), The Cambridge handbook of stylistics (pp. 13-31). Cambridge University Press.

Townshend, D. (2016). Gothic and the cultural sources of horror, 1740-1820. In Reyes, X. A. (Ed), Horror: A literary history (pp. 19-51). The British Library.

Turner, M. (2007). Conceptual integration. In D. Geeraerts, \& H. Cuyckens (Eds.), The Oxford handbook of cognitive linguistics (pp. 377-393). Oxford University Press.

Widdowson, H. G. (1972). On the deviance of literary discourse. Style. 6(3), 294-308. 


\section{AUTHORS' BIO}

Wesam Ali El-Sayed is an assistant lecturer and a Fulbright alumna with a demonstrated history of working in the higher education industry. She works at the Department of English, Faculty of Al-Alsun, Minia University, Egypt with an MA degree in English Linguistics, particularly Critical Discourse Analysis and media studies. She is currently doing her PhD in English Linguistics (particularly, cognitive stylistics) at the same faculty. Wesam has taught several courses at the university level including phonetics, essay writing, pragmatics, translation and historical linguistics. She also works as an Arabic-English/English-Arabic translator as well as a General English instructor in the Languages and Translations Center (LTC) at the faculty. 